\title{
Engineering Protein Hydrogels Using SpyCatcher-SpyTag Chemistry
}

\author{
Xiaoye Gao ${ }^{1 \#}$, Jie Fang ${ }^{1 \#}$, Bin Xue ${ }^{2}$, Linglan $\mathrm{Fu}^{1}$ and Hongbin $\mathrm{Li}^{1 *}$
}

\section{Supporting Information}
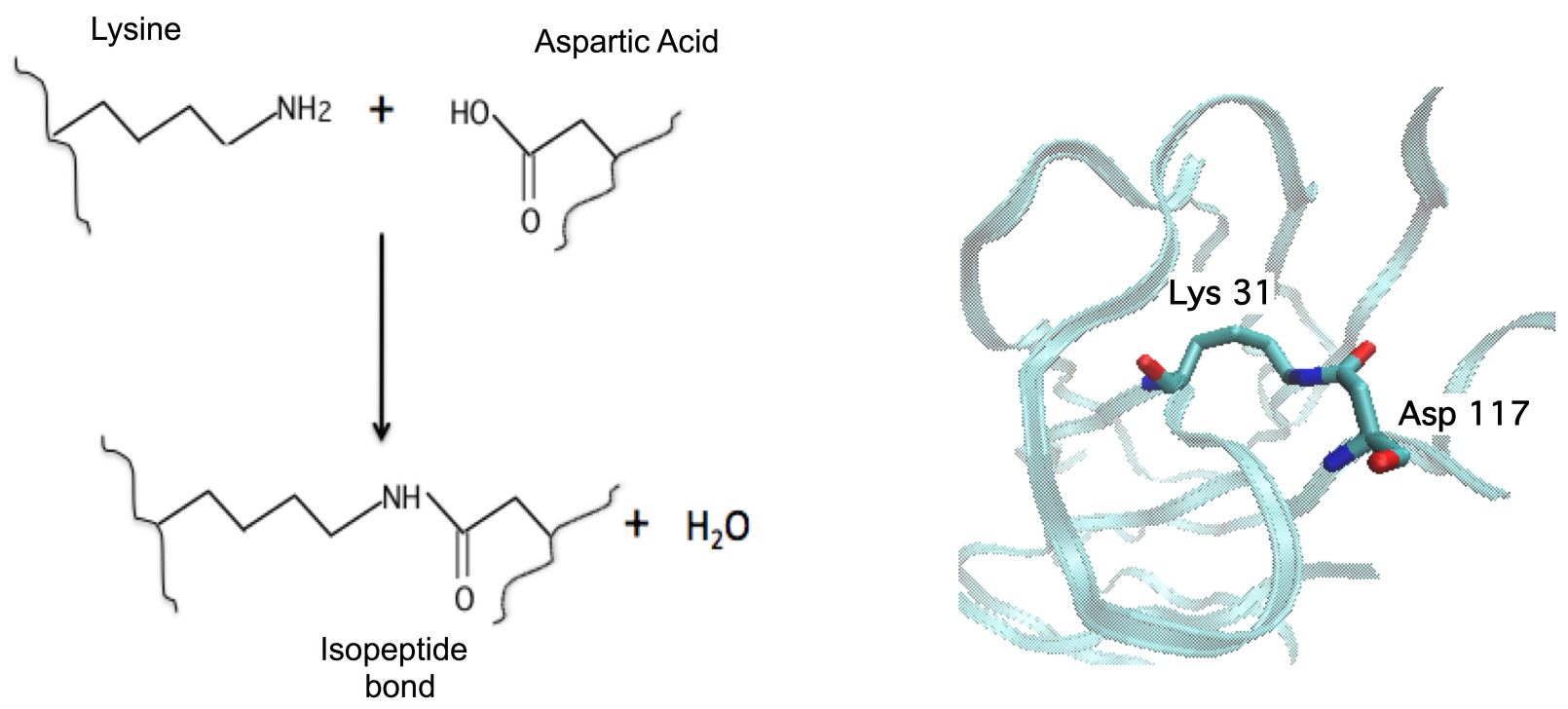

Figure S1. SpyCatcher-SpyTag chemistry. Reaction of the side chains of Lys and Asp leads to the formation of an amide bond, isopeptide bond. Key residues for the isopeptide bond formation in $\mathrm{CnaB} 2$ are shown in stick format (PDB code 2X5P). 
GB1-Sc

MRGSHHHHHHGSMDTYKLILNGKTLKGETTTEAVDAATAEKVFKQYANDNGVDGEWTYDDA TKTFTVTERSGAMVDTLSGLSSEQGQSGDMTIEEDSATHIKFSKRDEDGKELAGATMELRDSSG KTISTWISDGQVKDFYLYPGKYTFVETAAPDGYEVATAITFTVNEQGQVTVNGKATKGDAHI

GB1-St

MRGSHHHHHHGSMDTYKLILNGKTLKGETTTEAVDAATAEKVFKQYANDNGVDGEWTYDDA TKTFTVTEAHIVMVDAYKPTK

$(\mathrm{GB} 1-\mathrm{St})_{2}$

MRGSHHHHHHGSMDTYKLILNGKTLK GETTTEAVDAATAEKVFKQYANDNGVDGEWTYDDA TKTFTVTERSAHIVMVDAYKPTKRSMDTYKLILNGKTLKGETTTEAVDAATAEKVFKQYANDN GVDGEWTYDDATKTFTVTERSAHIVMVDAYKPTK

$(\mathrm{GB} 1-\mathrm{Sc})_{3}$ :

MRGSHHHHHHGSMDTYKLILNGKTLKGETTTEAVDAATAEKVFKQYANDNGVDGEWTYDDA TKTFTVTERSGAMVDTLSGLSSEQGQSGDMTIEEDSATHIKFSKRDEDGKELAGATMELRDSSG KTISTWISDGQVKDFYLYPGKYTFVETAAPDGYEVATAITFTVNEQGQVTVNGKATKGDAHIRS MDTYKLILNGKTLKGETTTEAVDAATAEKVFKQYANDNGVDGEWTYDDATKTFTVTERSGAM VDTLSGLSSEQGQSGDMTIEEDSATHIKFSKRDEDGKELAGATMELRDSSGKTISTWISDGQVKD FYLYPGKYTFVETAAPDGYEVATAITFTVNEQGQVTVNGKATKGDAHIRSMDTYKLILNGKTLK GETTTEAVDAATAEKVFKQYANDNGVDGEWTYDDATKTFTVTERSGAMVDTLSGLSSEQGQS GDMTIEEDSATHIKFSKRDEDGKELAGATMELRDSSGKTISTWISDGQVKDFYLYPGKYTFVETA APDGYEVATAITFTVNEQGQVTVNGKATKGDAHI

TNfn3-(GB1-Sc) $)_{3}$

MRGSHHHHHHGSRLDAPSQIEVKDVTDTTALITWFKPLAEIDGIELTYGIKDVPGDRTTIDLTEDE NQYSIGNLKPDTEYEVSLISRRGDMSSNPAKETFTTRSMDTYKLILNGKTLKGETTTEAVDAATA EKVFKQYANDNGVDGEWTYDDATKTFTVTERSGAMVDTLSGLSSEQGQSGDMTIEEDSATHIK FSKRDEDGKELAGATMELRDSSGKTISTWISDGQVKDFYLYPGKYTFVETAAPDGYEVATAITFT VNEQGQVTVNGKATKGDAHIRSMDTYKLILNGKTLKGETTTEAVDAATAEKVFKQYANDNGV DGEWTYDDATKTFTVTERSGAMVDTLSGLSSEQGQSGDMTIEEDSATHIKFSKRDEDGKELAGA TMELRDSSGKTISTWISDGQVKDFYLYPGKYTFVETAAPDGYEVATAITFTVNEQGQVTVNGKA TKGDAHIRSMDTYKLILNGKTLKGETTTEAVDAATAEKVFKQYANDNGVDGEWTYDDATKTF TVTERSGAMVDTLSGLSSEQGQSGDMTIEEDSATHIKFSKRDEDGKELAGATMELRDSSGKTIST WISDGQVKDFYLYPGKYTFVETAAPDGYEVATAITFTVNEQGQVTVNGKATKGDAHI

$(\mathrm{GB} 1-\mathrm{St})_{4}$ :

MRGSHHHHHHGSMDTYKLILNGKTLKGETTTEAVDAATAEKVFKQYANDNGVDGEWTYDDA TKTFTVTERSAHIVMVDAYKPTKRSMDTYKLILNGKTLKGETTTEAVDAATAEKVFKQYANDN GVDGEWTYDDATKTFTVTERSAHIVMVDAYKPTKRSMDTYKLILNGKTLKGETTTEAVDAATA EKVFKQYANDNGVDGEWTYDDATKTFTVTERSAHIVMVDAYKPTKRSMDTYKLILNGKTLKG ETTTEAVDAATAEKVFKQYANDNGVDGEWTYDDATKTFTVTERSAHIVMVDAYKPTK

Figure S2. Amino acid sequence of the constructed proteins. Sequences are color-coded according to their origins. Sequences in black are purification tags or resulted from restriction sites used in cloning. 


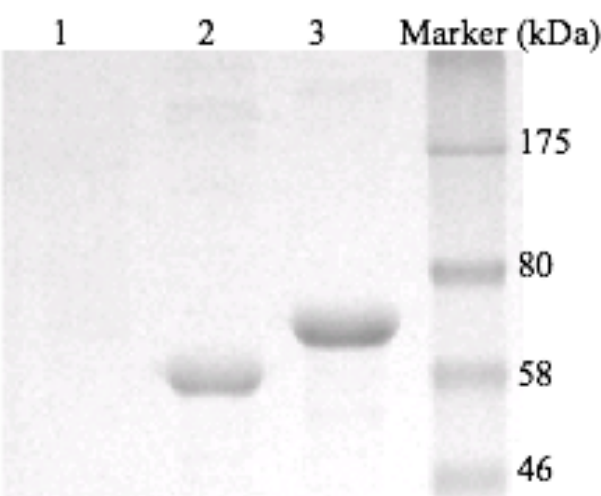

30

Figure S3. SDS-PAGE analysis of the constructed SpyCatcher and SpyTag-containing polyproteins. Lane1: $(\mathrm{GSt})_{4}$; Lane 2: $(\mathrm{GSc})_{3}$ and Lane 3: TNfn3 $(\mathrm{GSc})_{3}$. 




Figure S4. Swelling ratio of the $(\mathrm{GSc})_{3} /(\mathrm{GSt})_{4}$ hydrogels in PBS. The error bars indicate standard deviation $(n=3)$. 


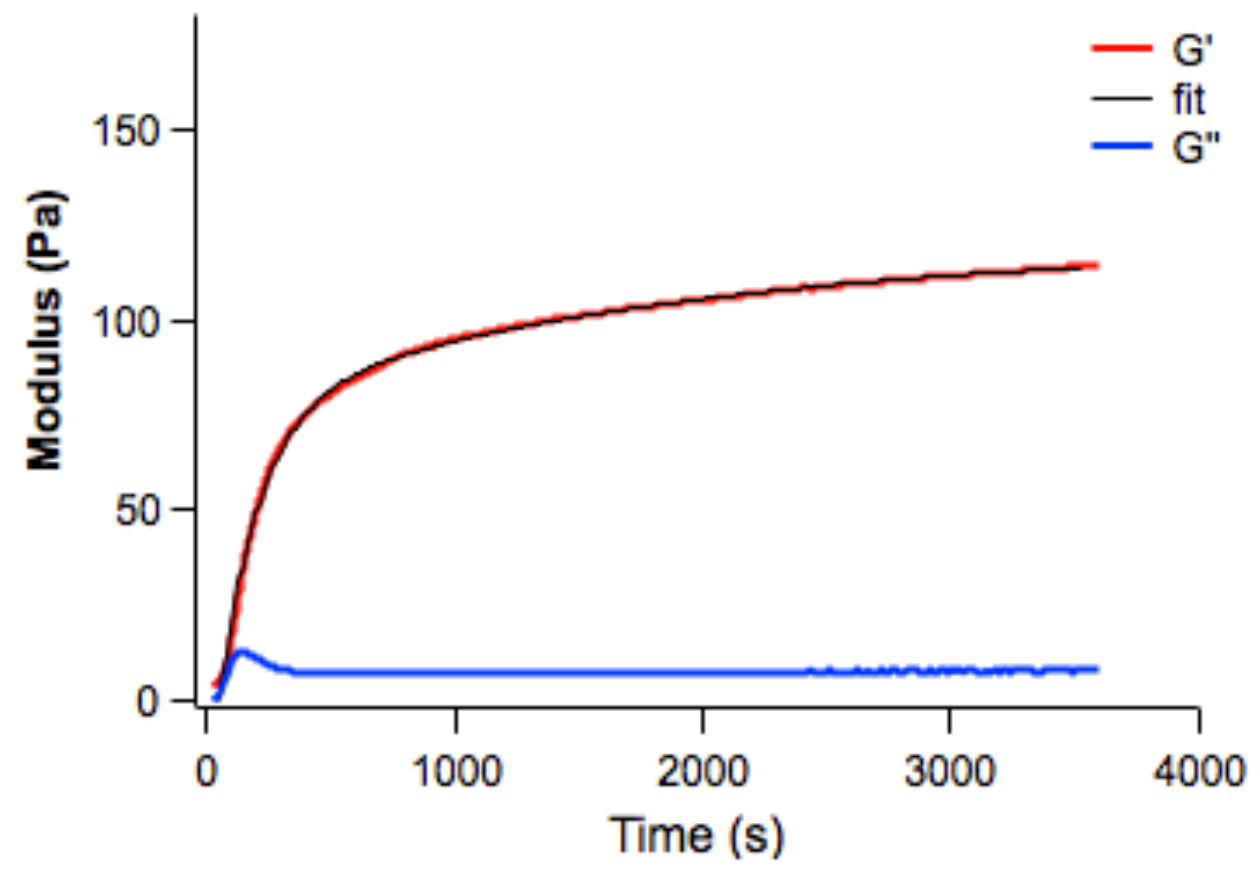

Figure S5. Time sweep test of the $5 \%(\mathrm{GSc})_{3} /(\mathrm{GSt})_{4}$ hydrogel at $20^{\circ} \mathrm{C}$. Both $\mathrm{G}^{\prime}$ and $\mathrm{G}$ ', were monitored. The evolution of G' can be described by a double exponential fit (in black) with a half-life of 164 seconds for the fast phase, and a half-life of 1760 seconds for the slow phase. 



Figure S6. Frequency (A and C) and strain sweep test (B and D) of the 10\% and 15\% $\mathrm{GSc}) 3 /(\mathrm{GSt}) 4$ hydrogel at $20^{\circ} \mathrm{C}$. Both $\mathrm{G}^{\prime}$ and $\mathrm{G}$ ” were monitored. 